\title{
Changes in hematological, biochemical, and blood gases parameters in response to progressive inclusion of nitrate in the diet of Holstein calves
}

\author{
Abimael Ortiz-Chura1(D), Gisela Marcoppido1(D), José Gere²(D), Gustavo Depetris ${ }^{3}$ (D) Francisco Stefañuk ${ }^{3}$, \\ Marcos D. Trangoni ${ }^{4}$, Silvio L. Cravero ${ }^{4}$, Claudia Faverín ${ }^{3}$ (D), Angel Cataldi ${ }^{4}$ (i) and María E. Cerón-Cucchi ${ }^{1}$ (D)
}

1. Institute of Pathobiology, National Institute of Agricultural Technology, National Scientific and Technical Research Council, Hurlingham (C1686), Argentina; 2. Engineering Research and Development Division, National Technological University, National Scientific and Technical Research Council, Ciudad Autónoma de Buenos Aires (C1179), Argentina;

3. Agricultural Experimental Station of Balcarce, National Institute of Agricultural Technology, Balcarce (B7620), Argentina; 4. Institute of Agrobiotechnology and Molecular Biology, National Institute of Agricultural Technology, National Scientific and Technical Research Council, Hurlingham (C1686), Argentina.

Corresponding author: María E. Cerón-Cucchi, e-mail: ceroncucchi.maria@inta.gob.ar

Co-authors: AO: ortiz.abimael@inta.gob.ar, GM: marcoppido.gisela@inta.gob.ar, JG: jotandil@gmail.com, GD: depetris.gustavo@inta.gob.ar, FS: stefanuk.francisco@inta.gob.ar, MDT: trangoni.marcos@inta.gob.ar, SLC: cravero.silvio@inta.gob.ar, CF: faverin.claudia@inta.gob.ar, AC: cataldi.angeladrian@inta.gob.ar

Received: 20-08-2020, Accepted: 26-11-2020, Published online: 09-01-2021

doi: www.doi.org/10.14202/vetworld.2021.61-69 How to cite this article: Ortiz-Chura A, Marcoppido G, Gere J, Depetris G, Stefañuk F, Trangoni MD, Cravero SL, Faverín C, Cataldi A, Cerón-Cucchi ME (2021) Changes in hematological, biochemical, and blood gases parameters in response to progressive inclusion of nitrate in the diet of Holstein calves, Veterinary World, 14(1): 61-69.

\begin{abstract}
Background and Aim: Nitrate $\left(\mathrm{NO}_{3}\right)$ reduces enteric methane emissions and could be a source of non-protein nitrogen in ruminant feeds. Nonetheless, it has a potential toxic effect that could compromise animal health and production. The purpose of this study was to determine the effects of progressive inclusion of $\mathrm{NO}_{3}^{-}$in the diet on the hematological, biochemical, and blood gases parameters, in turn, the effects on feed intake and live weight gain (LWG) in Holstein calves.
\end{abstract}

Materials and Methods: Eighteen Holstein heifers and steers (nine animals/treatment) were maintained in individual pens for 45 days. Animals were randomly allocated to either a control or nitrate diet (ND) (containing $15 \mathrm{~g}$ of $\mathrm{NO}_{3}^{-} / \mathrm{kg}^{-}$of dry matter $[\mathrm{DM}])$. The biochemical parameters and blood gases were analyzed only in the $\mathrm{NO}_{3}^{-}$group on days: $-1,1,7,13,19$, and 25 corresponding to $0,20,40,60,80$, and $100 \%$ of the total inclusion of $\mathrm{NO}_{3}^{-}$in the diet, respectively. In addition, DM intake (DMI) and LWG were evaluated among dietary treatments.

Results: Feeding the ND did not influence DMI or LWG ( $p>0.05$ ). Methemoglobin (MetHb) and deoxyhemoglobin increased according to the $\mathrm{NO}_{3}^{-}$concentrations in the diet $(\mathrm{p}<0.05)$, while an opposite effect was observed for oxyhemoglobin and carboxyhemoglobin $(\mathrm{p}<0.05)$. Hematocrit levels decreased $(\mathrm{p}<0.05)$, while albumin, alanine aminotransferase, and gammaglutamyl transpeptidase concentrations were not modified $(\mathrm{p}>0.05)$. However, glucose, urea, aspartate aminotransferase $(\mathrm{AST})$, and retinol concentrations increased $(\mathrm{p}<0.05)$ according to the $\mathrm{NO}_{3}^{-}$concentrations in the diet.

Conclusion: This study confirmed that the progressive inclusion of $123 \mathrm{~g}$ of $\mathrm{NO}_{3}^{-} /$animal/day in the diet could be safe without affecting DMI and LWG of Holstein calves. In turn, a dose-response effect of the MetHb, glucose, urea, AST, and retinol was observed, but these values did not exceed reference values. These results highlighted the importance of using a scheme of progressive inclusion of $\mathrm{NO}_{3}^{-}$in the diet of calves to reduce the risks of $\mathrm{NO}_{3}^{-}$toxicity.

Keywords: dry matter intake, liver function, methemoglobin, nitrate toxicity.

\section{Introduction}

The use of nitrate $\left(\mathrm{NO}_{3}\right)$ in ruminants' diet decreases enteric methane $\left(\mathrm{CH}_{4}\right)$ emissions, which tested in in vitro and in vivo studies, showing effective and persistent results as an option in methane mitigation [1]. This reduction relies on that $\mathrm{NO}_{3}^{-}$consumes more electrons at the expense of $\mathrm{CH}_{4}$ production, by reducing it to nitrite $\left(\mathrm{NO}_{2}\right)$ and also to ruminal ammonia $\left(\mathrm{NH}_{3}\right)$ [2]. In this sense, the presence of $\mathrm{NO}_{3}^{-}$in the rumen drives a shift in the use of hydrogen $\left(\mathrm{H}_{2}\right)$

Copyright: Ortiz-Chura, et al. Open Access. This article is distributed under the terms of the Creative Commons Attribution 4.0 International License (http://creativecommons.org/licenses/ by/4.0/), which permits unrestricted use, distribution, and reproduction in any medium, provided you give appropriate credit to the original author(s) and the source, provide a link to the Creative Commons license, and indicate if changes were made. The Creative Commons Public Domain Dedication waiver (http:// creativecommons.org/publicdomain/zero/1.0/) applies to the data made available in this article, unless otherwise stated. toward $\mathrm{NH}_{3}$ production instead of $\mathrm{CH}_{4}$ production [2]. However, when the input of $\mathrm{NO}_{3}^{-}$exceeds the ruminal microbiota ability for $\mathrm{NO}_{3}^{-}$reduction, this mechanism is altered, causing the $\mathrm{NO}_{2}^{-}$to accumulate in the rumen and pass into the bloodstream, resulting in increased methemoglobinemia in ruminants [3]. Signs of $\mathrm{NO}_{3}^{-}$ toxicity may appear when more than $20 \%$ of the hemoglobin is converted to methemoglobin (MetHb) [4]. Symptoms depend on the degree of exposure to $\mathrm{NO}_{3}^{-}$, such as decreased feed intake resulting in reduced live weight gain (LWG), susceptibility to infections, reproductive inefficiency, brown mucous membrane discoloration, respiratory distress, coma, cyanosis, and even death [5].

A key condition for the use of $\mathrm{NO}_{3}^{-}$or other additives as anti-methanogenic agents is that they do not develop harmful effects on animal health and performance [6]. Several strategies have been developed 
to reduce the risks of toxicity by $\mathrm{NO}^{3}$ inclusion in the diet, such as $\mathrm{NO}_{3}^{-}$encapsulation [7] and forages sprayed with $\mathrm{NO}_{3}^{-}[8]$. In addition, the gradual adaptation to $\mathrm{NO}_{3}^{-}$in the diet could be an alternative to minimize negative effects. The previous study have shown that progressive inclusion of $\mathrm{NO}_{3}^{-}$in the diet did not compromise animal performance, produced no toxic effects, and had no cumulative effects on the animal products [9]. However, these previous studies were focused only on assessing the effects on the abatement capacity of enteric $\mathrm{CH}_{4}$ emissions, and monitoring of blood MetHb as the unique indicator of $\mathrm{NO}_{3}^{-}$ toxicity $[10,11]$. In this sense, many studies have often ignored hematological, biochemical, and blood gases changes during the adaptation period to dietary $\mathrm{NO}_{3}^{-}$, although the importance of the inclusion of these compounds on animal health.

The mitigation potential of $\mathrm{NO}_{3}^{-}$can not only be beneficial in intensive milk and meat production systems but can also be especially interesting in pasture-based livestock systems that use low protein forages to maintain animal production (mainly during the dry season), because the ruminal microbiota of the host animal can benefit from $\mathrm{NO}_{3}^{-}$as a non-protein nitrogen source and use it for microbial protein synthesis. Therefore, the use of $\mathrm{NO}_{3}^{-}$would not only reduce the environmental impact but also improve animal performance, such as was evidenced in the study by Wang et al. [12].

Our study highlights the importance of the adaptation period and animal response to $\mathrm{NO}_{3}^{-}$in the diet. We hypothesize that the progressive inclusion of $\mathrm{NO}_{3}^{-}$in the diet allows an effective adaptation of the $\mathrm{NO}_{3}^{-}$reducing ruminal microbiota, which causes a dose-response effect on hematological, biochemical, and blood gases parameters without reaching toxicity levels for the animal, and without causing changes in animal performance. Thus, the aim of this study was to evaluate the effects of progressive inclusion of $\mathrm{NO}_{3}^{-}$in the diet on the hematological, biochemical, and blood gases parameters, in turn, the effects on feed intake and LWG in Holstein calves.

\section{Materials and Methods}

\section{Ethical approval}

This study was performed in accordance with international recommendations specified in the guidelines for the use and care of animals. All the animal procedures used in this study were approved by the Committee for Use and Care of Experimental Animals (Protocol CICUAE/124-2017; Approval date September 12, 2017) of the National Institute of Agricultural Technology (INTA) of Argentina.

\section{Study location, period, experimental design and ani- mal procedures}

The experiment was conducted at the Experimental Dairy Centre of the Balcarce Agricultural Experimental Station of INTA, Argentina $\left(37^{\circ} 45^{\prime} 37^{\prime \prime} \mathrm{S} ; 58^{\circ} 17^{\prime} 55^{\prime \prime} \mathrm{W}\right)$, during the period from
October 20 to December 4, 2017. Eighteen calves (seven heifers and 11 steers) of $8.1 \pm 0.5$ months of age (mean \pm standard deviation) and with $214 \pm 13.5 \mathrm{~kg}$ live weight were used. The calves were considered clinically healthy based on physical examination and blood sample results (biochemical and hematological parameters). During the study period, daily physical examination of the animals was performed, and potential lack of appetite, mucosal color or other abnormal signs were recorded. As a precautionary protocol, against intoxication of $\mathrm{NO}_{3}^{-}$, a solution of methylene blue was prepared for emergency use, at a dose of $15 \mathrm{mg} / \mathrm{kg}$ of body weight (intravenous administration).

The animals were randomly allocated to either a control diet (CD; including five steers and four heifers) or a nitrate diet (ND; including six steers and three heifers). The $\mathrm{CD}$ group received a total mix ration ( $\%$ of dry matter $[\mathrm{DM}]$ ) of corn ground, soybean meal, premix, and urea $(79.6 \%)$, and grass hay $(20.4 \%)$. In turn, the ND group received CD $\left(98.5 \%\right.$ ) plus $1.5 \%$ of $\mathrm{NO}_{3}^{-}$(as calcium $\mathrm{NO}_{3}^{-}$, YaraLiva Calcinit ${ }^{\mathbb{R}}$, Yara Argentina S.A.) (Table-1). The intermediate level of $\mathrm{NO}_{3}^{-}$inclusion in the diet was selected for this study because it was previously used to mitigate enteric $\mathrm{CH}_{4}$ emissions in Holstein cattle without compromising animal health $[10,13]$.

To reduce the risks of toxicity, the amount of $\mathrm{NO}_{3}^{-}$ was gradually increased (Table-2). The animals were fed ad libitum twice a day (08:00 AM and 4:00 PM) in individual pens $\left(36 \mathrm{~m}^{2}\right)$ provided with individual feeders and shared drinking troughs. The trial included 30 days of adaptation period to the diet and handling, followed by a 15 days measurement period (from day 31 to day 45).

Table-1: Dietary ingredients (\% of DM) and nutritional composition of experimental diets (\% of DM).

\begin{tabular}{lcc}
\hline Variable & CD & ND \\
\hline Ingredients & & \\
$\quad$ Grass hay & 20.4 & 20.4 \\
Ground corn & 69.4 & 68.3 \\
Soybean expeller & 8.0 & 8.4 \\
Urea & 0.8 & 0.2 \\
Calcium nitrate* & 0.0 & 1.5 \\
Premix & 1.1 & 1.1 \\
Total & 100 & 100 \\
Composition & & \\
Dry matter (\% of FM) & 90.4 & 90.5 \\
Organic matter (\% of DM) & 94.5 & 94.5 \\
Crude protein (\% of DM) & 12.4 & 12.2 \\
Neutral detergent fiber (\% of DM) & 25.9 & 25.8 \\
Starch (\% of DM) & 48.3 & 47.6 \\
GE (MJ/kg of DM) & 21.3 & 21.3 \\
\hline
\end{tabular}

$\mathrm{DM}=$ Dry matter, $\mathrm{FM}=$ Fresh matter, $\mathrm{GE}=$ Gross energy, $\mathrm{CD}=$ Control diet, $\mathrm{ND}=$ Nitrate diet. ${ }^{*}$ Calcium ammonium nitrate, $5 \mathrm{Ca}\left(\mathrm{NO}_{3}\right)_{2} \cdot \mathrm{NH}_{4} \mathrm{NO}_{3}^{\bullet} 10 \mathrm{H}_{2} \mathrm{O} ; 75 \% \mathrm{NO}_{3}$ on dry basis; estimated composition $11.3 \mathrm{~g} \mathrm{NO}_{3}^{-} / \mathrm{kg} \mathrm{DM}$ for nitrate treatment. ${ }^{*}$ Composition of Premix (per kg of premix): Calcium 23\%, Sodium 8\%, Phosphorus 1\%, Magnesium 3,1\%, Vitamin A 150000 UI, Vitamin D3 15000 UI, Vitamin E 150 UI, Iron 960 ppm, Magnesium 900 ppm, Zinc 900 ppm, Copper 150 ppm, Iodine 24 ppm, Cobalt 15 ppm, Selenium 6 ppm 
Table-2: Scheme of progressive adaptation to a diet with $\mathrm{NO}_{3}^{-}$inclusion.

\begin{tabular}{lccccc}
\hline Phase & $\mathbf{1}$ & $\mathbf{2}$ & $\mathbf{3}$ & $\mathbf{4}$ & $\mathbf{6}$ \\
\hline Day & $1-6$ & $7-12$ & $13-18$ & $19-24$ & $25-30$ \\
Calcium nitrate* (\%) & 20 & 40 & 60 & 80 & 100 \\
g/animal/day & 24.6 & 49.2 & 73.8 & 100 \\
\hline
\end{tabular}

*Percentage of $\mathrm{NO}_{3}^{-}$inclusion in each phase was according to the total intake on day $25\left(15 \mathrm{~g}^{\circ} \mathrm{NO}_{3}^{-} / \mathrm{kg}\right.$ of DM)

\section{Blood sampling and analysis}

Blood samples were taken only from the ND group. For blood gas (MetHb, oxyhemoglobin $\left[\mathrm{O}_{2} \mathrm{Hb}\right]$, carboxyhemoglobin [COHb], and deoxyhemoglobin $[\mathrm{HHb}])$, hematocrit, and glucose monitoring, the sampling was performed $3 \mathrm{~h}$ post-feeding on days-1 (control day), 1, 7, 13, 19, and 25, by jugular vein puncture using Vacuette ${ }^{\circledR}$ tubes with lithium heparin (Greiner Bio-One GmbH - Germany), and placed on ice directly after sampling. The analytes were determined using the Cobas-b221 blood gas system (Roche Diagnostics, USA).

In addition, the serum concentration of urea, albumin, aspartate aminotransferase (AST), alanine aminotransferase (ALT), gamma-glutamyl transpeptidase (GGT), and retinol was monitored, to examine liver function. Blood sampling on days-1 (control day), 7, and 25 were transferred into tubes with clot activator and gel separator (Greiner Bio-One GmbH - Germany). After clotting, serum was separated by low-speed centrifugation $(3500 \times g)$ for $15 \mathrm{~min}$ at $4{ }^{\circ} \mathrm{C}$ and stored at $-20^{\circ} \mathrm{C}$ until analysis. The concentrations of urea and albumin were determined by the enzymatic method UV-glutamate dehydrogenase and colorimetrically with bromine cresol-sulfonephthalein, respectively [14], while AST and ALT and GGT were determined using an automatic biochemistry analyzer $[15,16]$. Retinol was determined as an indicator of Vitamin A by high-performance liquid chromatography.

\section{Evaluation of DM intake (DMI), LWG, and diets analysis}

DMI was calculated as the difference between the daily offered and residual feed. Only measures of DMI from day 31 to day 45 (post-adaptation period) were considered for the analysis of the data. The results were expressed in kilograms of DMI/day. The LWG was determined as the difference between the final and initial weight during 45 days of evaluation and was expressed in kilograms of LWG/day.

The ingredients of the diets were dried in a forced-air oven at $55^{\circ} \mathrm{C}$ and milled to pass a $1-\mathrm{mm}$ screen. DM analysis by oven drying $\left(105^{\circ} \mathrm{C}\right)$ and ash by incineration at $550^{\circ} \mathrm{C}$ for $4 \mathrm{~h}$ were determined, according to AOAC [17]. Total nitrogen content was determined by combustion type auto-analyzer (Leco FP-2000, Leco Corp., St. Joseph, MI). In addition, we assessed neutral detergent fiber in a fiber analyzer ANKOM ${ }^{\circledR} 220$ (ANKOM Technology, Macedon NY-USA) [18], and starch was analyzed by an enzymatic method [19].

\section{Statistical analysis}

The results of DMI and LWG were analyzed with PROC MIXED SAS software version 13.1 (SAS Institute Inc., Cary NC, USA 2013) [20] with treatment as fixed effect and animals as random effect according to the model $Y_{i j}=\mu+$ Treat $_{i}+$ Anim $_{j}$ (Treat) $+e_{i j}$, where: $\mathrm{Y}_{i j}=$ response variable; $\mu=$ general mean of the experiment; Treat $=$ Treatment, $\mathrm{CD}$ versus ND $(i=2)$; Anim $_{j}($ Treat $)=$ animals within the treatment $(j=18)$; $e_{i j}=$ experimental error.

Urea, albumin, retinol, AST, ALT, and GGT data were analyzed with the time factor as a repeated measure using PROC GLM of the SAS version 13.1 (SAS Institute Inc., Cary NC, USA 2013) [20], according to the following model: $Y_{i j}=\mu+$ Anim $_{i}+$ Time $_{j}+e_{i j}$, where: $Y_{i j}=$ response variable; $\mu=$ general mean of the experiment; Anim $_{i}=$ animals $(i=9)$; Time $_{j}=$ time factor: sampling day $(j=6$ or 3$)$; $e_{i j}=$ experimental error, in turn, followed by Dunnett's multiple comparison tests.

The data that did not meet the assumption of normality and homogeneity of variance, such as MetHb, $\mathrm{O}_{2} \mathrm{Hb}, \mathrm{COHb}$, and $\mathrm{HHb}$, glucose and hematocrit were analyzed using the Friedman test and a comparison between median was performed using Wilcoxon signed-rank test in $\mathrm{R}$ software version 3.6.1 [21]. Differences among mean and median were considered significant when $p<0.05$. In addition, Spearman's correlation analysis was used to evaluate the association between variables using the corrplot function in $\mathrm{R}$.

\section{Results}

\section{Effect on DMI and LWG}

DMI and LWG did not differ among dietary treatments in Holstein calves ( $p=0.117$ and $p=0.439$, respectively; Table-3). Likewise, the initial and final weight of the calves did not differ significantly among dietary treatments $(\mathrm{p}=0.960$ and $\mathrm{p}=0.832$, respectively).

\section{Effect on hematological, biochemical, and blood gases parameters}

An incremental effect was observed for MetHb (Figure-1), where levels increased numerically until day 19 , though not significantly compared to day- 1 . In contrast, on day 25 , there was a significant increase compared to day-1 $(\mathrm{p}<0.001)$. Moreover, an oppositive effect was observed for the $\mathrm{O}_{2} \mathrm{Hb}$ level, because it decreased according to $\mathrm{NO}_{3}^{-}$concentrations in the diet, although there was a significant decrease only on day 25 compared to day- $1(\mathrm{p}<0.001$; Table- 4$)$. In turn, the $\mathrm{COHb}$ values decreased significantly on days 1 , 13,19 , and 25 with respect to day- $1(\mathrm{p}=0.003)$, but 
statistically significant differences were not found between day 7 and day-1. Conversely, HHb increased significantly from day 1 to day 13 compared to day-1, and then there was a slight decrease toward day 25 , but remained higher than day- $1(\mathrm{p}=0.005)$.

The hematocrit was reduced according to $\mathrm{NO}_{3}^{-}$ concentrations in the diet $(\mathrm{p}=0.001)$. This reduction

Table-3: Dry matter intake and live weight gain in Holstein calves fed with a control diet $(n=9)$ and nitrate diet $(n=9)$.

\begin{tabular}{|c|c|c|c|c|}
\hline \multirow[t]{2}{*}{ Parameters } & \multicolumn{2}{|c|}{ Diets } & \multirow[t]{2}{*}{ SEM } & \multirow[t]{2}{*}{ p-value } \\
\hline & CD & ND & & \\
\hline Dry matter intake (kg/day) & 8.8 & 8.2 & 0.24 & 0.117 \\
\hline Initial weight (kg) & 214 & 214 & 4.76 & 0.960 \\
\hline Final weight $(\mathrm{kg})$ & 268 & 266 & 5.81 & 0.832 \\
\hline Live weight gain ( $\mathrm{kg} /$ day) & 1.2 & 1.1 & 0.10 & 0.439 \\
\hline
\end{tabular}

$\mathrm{SEM}=$ Standard error of the mean, $\mathrm{CD}=$ Control diet, $\mathrm{ND}=$ Nitrate diet was not associated with the hemolysis of blood samples because they were verified during laboratory analyses. In turn, glucose concentrations increased with $\mathrm{NO}_{3}^{-}$inclusion $(\mathrm{p}=0.001)$, being most evident on days 13,19 , and 25 , which corresponded to 60,80 , and $100 \%$ of $\mathrm{NO}_{3}^{-}$inclusion (Figure-2).

On the other hand, the changes of AST activity (Figure-3) and retinol concentrations (Figure-4) on day 7 (corresponding to $40 \%$ of total $\mathrm{NO}_{3}^{-}$) in comparison to day-1 were not different. However, on day 25, there was a significant increase with respect to day- $1 \quad(p=0.004$ and $p=0.025$, respectively). Similarly, there was a significant increase in urea concentrations from day 7 to day 25 compared to day-1 $(\mathrm{p}=0.001)$. However, the levels of $\mathrm{NO}_{3}^{-}$ inclusion in the diet did not modify albumin concentrations, and ALT and GGT activity ( $\mathrm{p}=0.387$, $\mathrm{p}=0.673$, and $\mathrm{p}=0.779$, respectively) in Holstein calves (Table-5).

Table-4: Effect of a progressive inclusion of $\mathrm{NO}_{3}^{-}$in the diet on blood gases (\%) and hematocrit (\%) levels in Holstein calves $(n=9)$.

\begin{tabular}{lcccccccc}
\hline \multirow{2}{*}{ Parameters } & \multicolumn{4}{c}{ Monitoring days (medians \pm IQR)* } & \multirow{2}{*}{ p-value } & \multirow{2}{*}{ Reference values } \\
\cline { 2 - 7 } & Day-1 & Day 1 & Day 7 & Day 13 & Day 19 & Day 25 & & \\
\hline $\mathrm{O}_{2} \mathrm{Hb}$ & $96 \pm 1.8^{\mathrm{a}}$ & $94 \pm 1.2^{\mathrm{a}}$ & $95 \pm 2.9^{\mathrm{a}}$ & $92 \pm 3.7^{\mathrm{a}}$ & $93 \pm 3.4^{\mathrm{a}}$ & $90 \pm 3.3^{\mathrm{b}}$ & 0.001 & $\mathrm{~N} / \mathrm{A}$ \\
$\mathrm{COHb}$ & $1.5 \pm 2.4^{\mathrm{a}}$ & $0.4 \pm 0.2^{\mathrm{a}}$ & $0.7 \pm 0.3^{\mathrm{a}}$ & $0.4 \pm 0.2^{\mathrm{b}}$ & $0.3 \pm 0.3^{\mathrm{b}}$ & $0.4 \pm 1.1^{\mathrm{b}}$ & 0.003 & $\mathrm{~N} / \mathrm{A}$ \\
$\mathrm{HHb}$ & $0.8 \pm 0.1^{\mathrm{a}}$ & $2.7 \pm 1.1^{\mathrm{b}}$ & $2.1 \pm 1.7^{\mathrm{b}}$ & $5.5 \pm 4.0^{\mathrm{b}}$ & $3.5 \pm 2.5^{\mathrm{b}}$ & $1.7 \pm 3.9^{\mathrm{b}}$ & 0.005 & $\mathrm{~N} / \mathrm{A}$ \\
$\mathrm{Hematocrit}$ & $32 \pm 1.7^{\mathrm{a}}$ & $30 \pm 0.8^{\mathrm{b}}$ & $29 \pm 1.8^{\mathrm{b}}$ & $29 \pm 0.8^{\mathrm{b}}$ & $29 \pm 1.3^{\mathrm{b}}$ & $29 \pm 0.5^{\mathrm{b}}$ & 0.001 & $30-36 \%$ Kahn and Line [38] \\
\hline
\end{tabular}

$\mathrm{O}_{2} \mathrm{Hb}=$ Oxyhemoglobin, $\mathrm{COHb}=$ Carboxyhemoglobin, $\mathrm{HHb}=$ Deoxyhemoglobin. IQR=Interquartile range. $\mathrm{N} / \mathrm{A}=\mathrm{Not}$ applicable. *Day-1=Without $\mathrm{NO}_{3}^{-}$in the diet (control day); Day $1=$ With $20 \%$ of total $\mathrm{NO}_{3}^{-}$in the diet; Day $7=$ With $40 \%$ of total $\mathrm{NO}_{3}^{-}$in the diet; Day $13=$ With $60 \%$ of total $\mathrm{NO}_{3}^{-}$in the diet; Day $19=$ With $80 \%$ of total $\mathrm{NO}_{3}^{-}$in the diet; Day $25=$ With $100 \% \mathrm{NO}_{3}^{-}$in the diet. a,bMedians within a row with different superscripts differ $(p<0.05)$ from Day-1 (Wilcoxon signed-rank test)

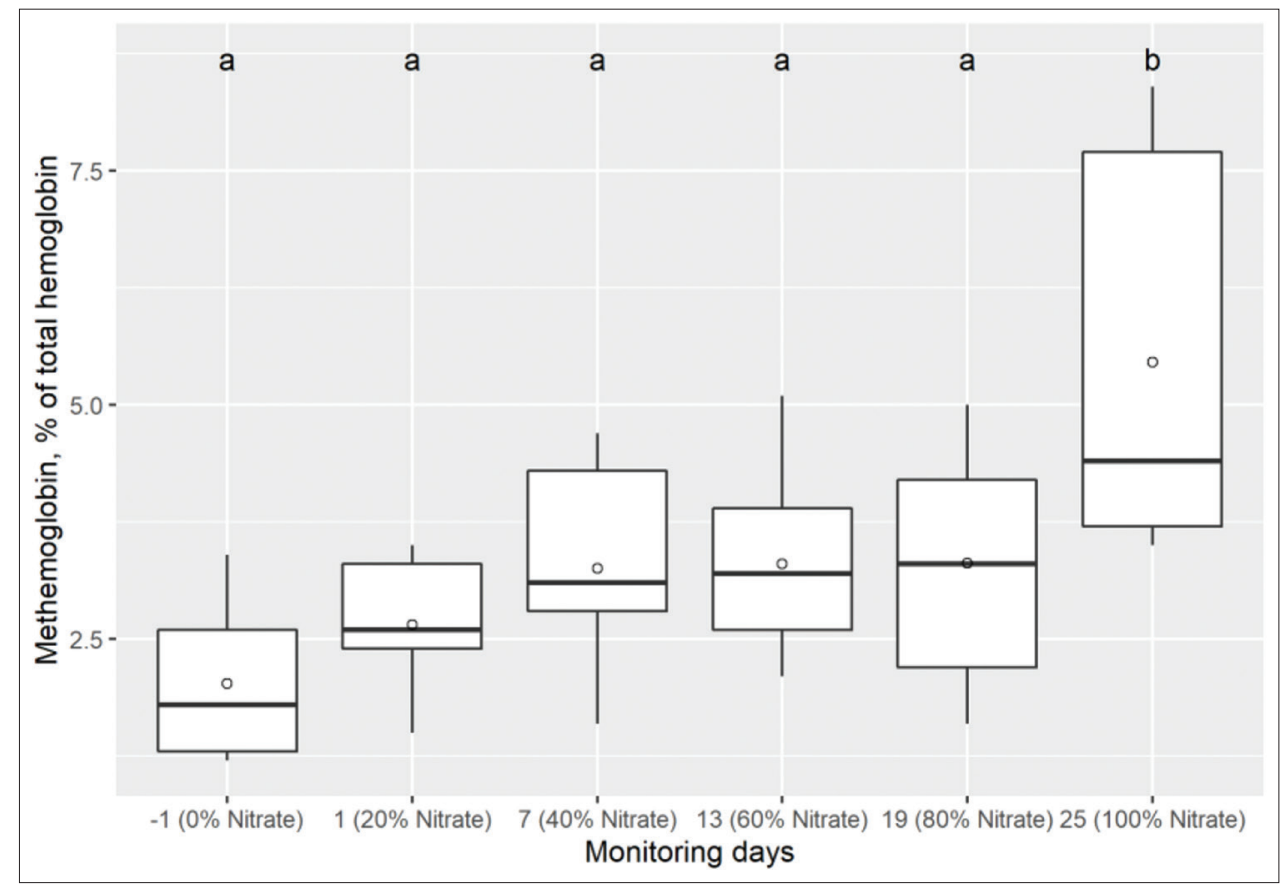

Figure-1: Box and whisker plots showing levels of methemoglobin (\% of total hemoglobin) in blood of nine Holstein calves measured on day-1, 1, 7, 13, 19, and 25 with $0,20,40,60,80$, and $100 \%$ of total $\mathrm{NO}_{3}^{-}$in the diet, respectively. The median is indicated by the middle line, the mean is indicated by the symbol $(0)$, and the $75^{\text {th }}$ and $25^{\text {th }}$ percentiles by the upper and lower edges of the boxes. The whiskers show the $95 \%$ confidence interval. Comparison of medians, box and whisker with different letters above ("a" or " $b$ ") differs $(p<0.05)$ from day-1 (range test signed by Wilcoxon). 


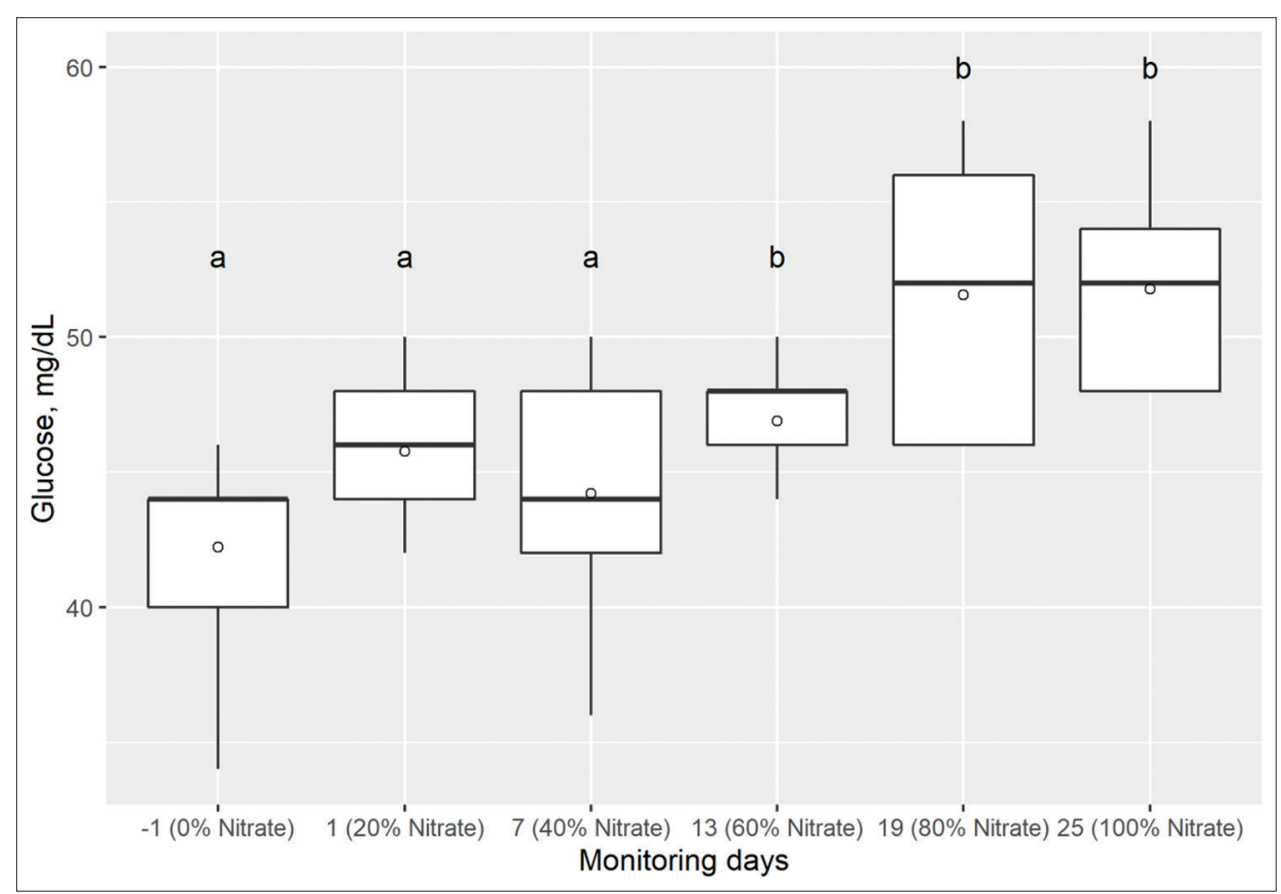

Figure-2: Box and whisker plots showing glucose concentrations $(\mathrm{mg} / \mathrm{dL})$ in blood of nine Holstein calves measured on day-1, 1, 7, 13, 19, and 25 with $0,20,40,60,80$, and $100 \%$ of total $\mathrm{NO}_{3}^{-}$in the diet, respectively. The median is indicated by the middle line, the mean is indicated by the symbol $(0)$, and the $75^{\text {th }}$ and $25^{\text {th }}$ percentiles by the upper and lower edges of the boxes. The whiskers show the $95 \%$ confidence interval. Comparison of medians, box and whisker with different letters above (" $a$ " or " $b$ ") differs $(p<0.05)$ from day-1 (range test signed by Wilcoxon). Reference values: $42-75 \mathrm{mg} / \mathrm{dL}$ Kahn and Line [38].

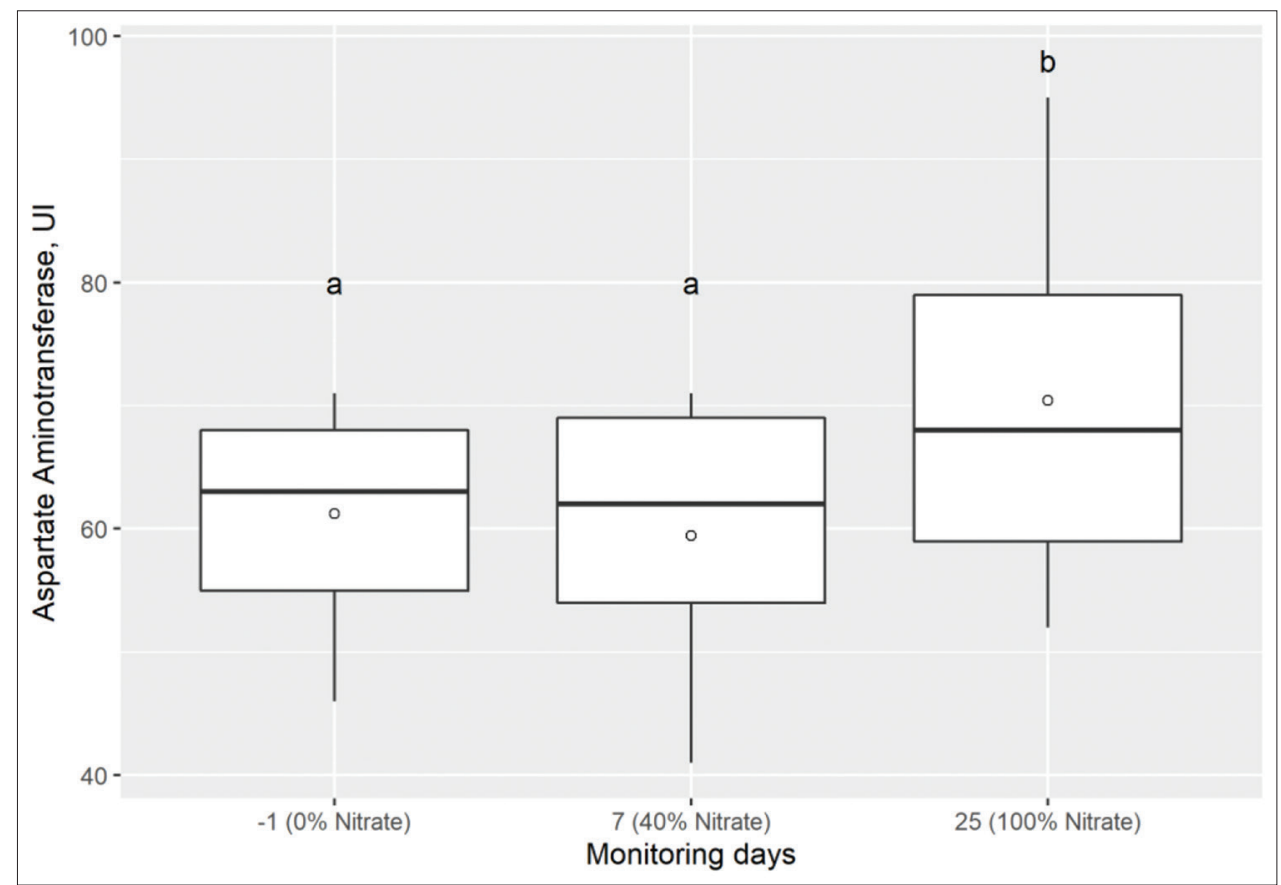

Figure-3: Box and whisker plots showing aspartate aminotransferase activity (UI) in serum of nine Holstein calves measured on day-1, 7, and 25 with 0,40 , and $100 \%$ of total $\mathrm{NO}_{3}^{-}$in the diet. The median is indicated by the middle line, the mean is indicated by the symbol $(0)$, and the $75^{\text {th }}$ and $25^{\text {th }}$ percentiles by the upper and lower edges of the boxes. The whiskers show the $95 \%$ confidence interval. Comparison of means, box and whisker with different letters above ("a" or " $b$ ") differs $(p<0.05)$ from day-1 (Dunnett's test). Reference values: 78-132 UI, Kaneko et al [37].

Correlation analysis of DMI, LWG, and blood parameters

Correlation analyses were performed with the hematological, biochemical, and blood gases variables corresponding to day 25 (Figure-5). DMI was positively associated with the level of $\mathrm{MetHb}$ $(\mathrm{r}=0.34), \mathrm{O}_{2} \mathrm{Hb}(\mathrm{r}=0.32), \operatorname{AST}(\mathrm{r}=0.38), \operatorname{ALT}(\mathrm{r}=0.44)$, and albumin $(\mathrm{r}=0.38)$. In contrast, it was negatively associated and in less degree with the concentration of glucose $(\mathrm{r}=-0.12), \mathrm{HHb}(\mathrm{r}=-0.30)$, hematocrit $(\mathrm{r}=-0.15)$, urea $(\mathrm{r}=-0.10)$, and retinol $(\mathrm{r}=-0.13)$. LWG was positively associated with glucose concentration $(\mathrm{r}=0.41), \mathrm{O}_{2} \mathrm{Hb}(\mathrm{r}=0.6)$, and $\mathrm{COHb}(\mathrm{r}=0.57)$, 
while, negatively with the concentration of MetHb $(\mathrm{r}=-0.2), \mathrm{HHb}(\mathrm{r}=-0.27)$, Urea $(\mathrm{r}=-0.13)$, AST $(\mathrm{r}=-0.23)$, and GGT $(\mathrm{r}=-0.5)$. MetHb was negatively associated with glucose concentration $(\mathrm{r}=-0.73)$, and less so with $\mathrm{O}_{2} \mathrm{Hb}(\mathrm{r}=-0.15), \mathrm{COHb}(\mathrm{r}=-0.13), \mathrm{HHb}$ $(\mathrm{r}=-0.49)$, and AST $(\mathrm{r}=-0.25)$, but positively with retinol $(\mathrm{r}=0.39)$. Urea concentration was positively associated with $\mathrm{O}_{2} \mathrm{Hb}(\mathrm{r}=0.6)$ and ALT $(\mathrm{r}=0.38)$, and negatively with $\mathrm{HHb}(\mathrm{r}=-0.31)$ and albumin $(\mathrm{r}=-0.39)$. AST activity was positively correlated with ALT activity $(\mathrm{r}=0.7)$ and albumin concentration $(\mathrm{r}=0.68)$, and negatively with retinol $(\mathrm{r}=-0.41)$. GGT activity was negatively associated with ALT $(\mathrm{r}=-0.53)$ and $\mathrm{COHb}(\mathrm{r}=-0.54)$, and positively with retinol $(\mathrm{r}=0.45)$.

\section{Discussion}

The physiological response to $\mathrm{NO}_{3}^{-}$in animals was variable because the level of $\mathrm{NO}_{3}^{-}$toxicity depends on several factors: Dietary $\mathrm{NO}_{3}^{-}$dose levels, the rate of $\mathrm{NO}_{3}^{-}$intake, an incomplete reduction of $\mathrm{NO}_{3}^{-}$and $\mathrm{NO}_{2}^{-}$to $\mathrm{NH}_{3}$ in the rumen, and a low rate of rumen content passage, which results in higher retention of $\mathrm{NO}_{3}^{-}$or $\mathrm{NO}_{2}^{-}$in the rumen [22]. Thus, in this study, it was possible to control the majority of these risk factors by the progressive inclusion of $\mathrm{NO}_{3}^{-}$in the diet because it allowed the DMI and LWG not to differ between dietary treatments, despite observing a $7 \%$ numerical reduction in the $\mathrm{DMI}$ in the $\mathrm{DN}$, which could be attributed to the organoleptic characteristics of $\mathrm{NO}_{3}^{-}[5]$. Similar results were found in the previous studies $[23,24]$.

A linear relationship between levels of blood MetHb and dietary $\mathrm{NO}_{3}^{-}$was observed in a meta-analysis study [1]. In addition, Newbold et al. [25] showed that $\mathrm{CH}_{4}$ emissions decreased linearly with increasing dietary $\mathrm{NO}_{3}^{-}$level, but the risk of poisoning also increased with daily doses $>2.4 \mathrm{~g}$ of $\mathrm{NO}_{3}^{-} / \mathrm{kg}$ of DM. However, when $\mathrm{NO}_{3}^{-}$was used in intermediate doses $\left(13-21 \mathrm{~g}\right.$ of $\mathrm{NO}_{3}^{-} / \mathrm{kg}$ of DM/day) and adequate dietary

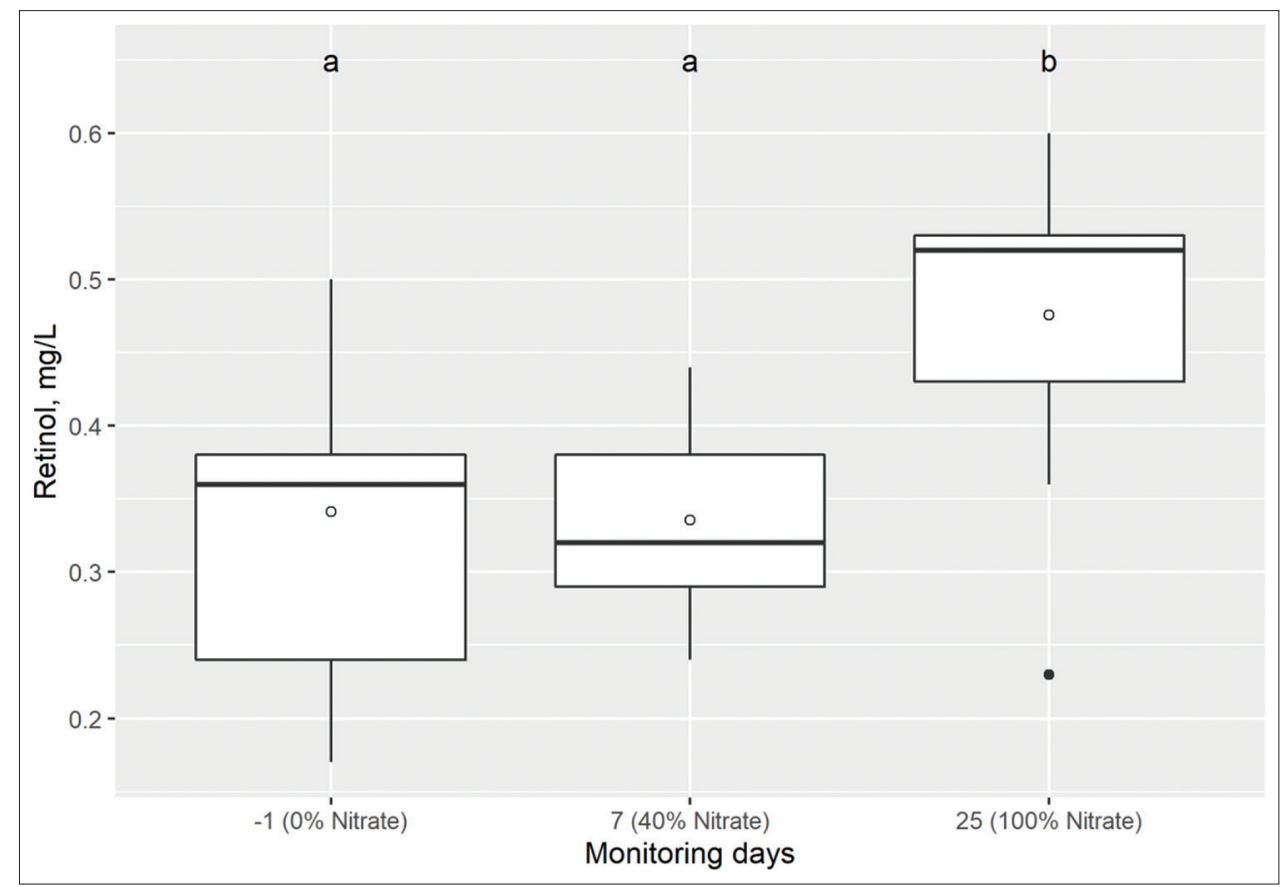

Figure-4: Box and whisker plots showing retinol concentrations $(\mathrm{mg} / \mathrm{L})$ in serum of 9 Holstein calves measured on day-1, 7 , and 25 with 0,40 , and $100 \%$ of total $\mathrm{NO}^{3}$ in the diet. The median is indicated by the middle line, the mean is indicated by the symbol $(0)$, and the $75^{\text {th }}$ and $25^{\text {th }}$ percentiles by the upper and lower edges of the boxes. The whiskers show the $95 \%$ confidence interval. Comparison of means, box and whisker with different letters above ("a" or "b") differs $(p<0.05)$ from day-1 (Dunnett's test). Reference values: Higher than $0.20 \mathrm{mg} / \mathrm{L}$, Bouda [36].

Table-5: Effect of a progressive inclusion of $\mathrm{NO}_{3}^{-}$in the diet on biochemical parameters and liver enzymes in blood serum of Holstein calves $(n=9)$.

\begin{tabular}{|c|c|c|c|c|c|c|}
\hline \multirow[t]{2}{*}{ Parameters } & \multicolumn{3}{|c|}{ Monitoring days (means)* } & \multirow[t]{2}{*}{ SEM } & \multirow[t]{2}{*}{ p-value } & \multirow[t]{2}{*}{ Reference values } \\
\hline & Day-1 & Day 7 & Day 25 & & & \\
\hline Urea (mg/dL) & $14^{\mathrm{a}}$ & $23^{b}$ & $21^{\mathrm{b}}$ & 0.93 & 0.001 & 10-25 Kahn and Line [38] \\
\hline Albumin $(\mathrm{g} / \mathrm{L})$ & 38 & 39 & 37 & 0.09 & 0.387 & 25-38 Kahn and Line [38] \\
\hline ALT (UI) & 16 & 16 & 17 & 0.97 & 0.673 & 11-40 Kaneko et al [37] \\
\hline GGT (UI) & 22 & 21 & 22 & 0.83 & 0.779 & 6.1-17.4 Kaneko et al [37] \\
\hline
\end{tabular}

ALT=Alanine aminotransferase, GGT=Gamma-glutamyl transpeptidase. SEM=Standard error of the mean.

*Day-1=Without $\mathrm{NO}_{3}^{-}$in the diet; Day $7=$ With $40 \%$ of total $\mathrm{NO}_{3}^{-}$in the diet; day $25=$ With $100 \% \mathrm{NO}_{3}^{-}$in the diet. a,bMeans within a row with different superscripts differ $(p<0.05)$ from Day-1 (Dunnett's test) 


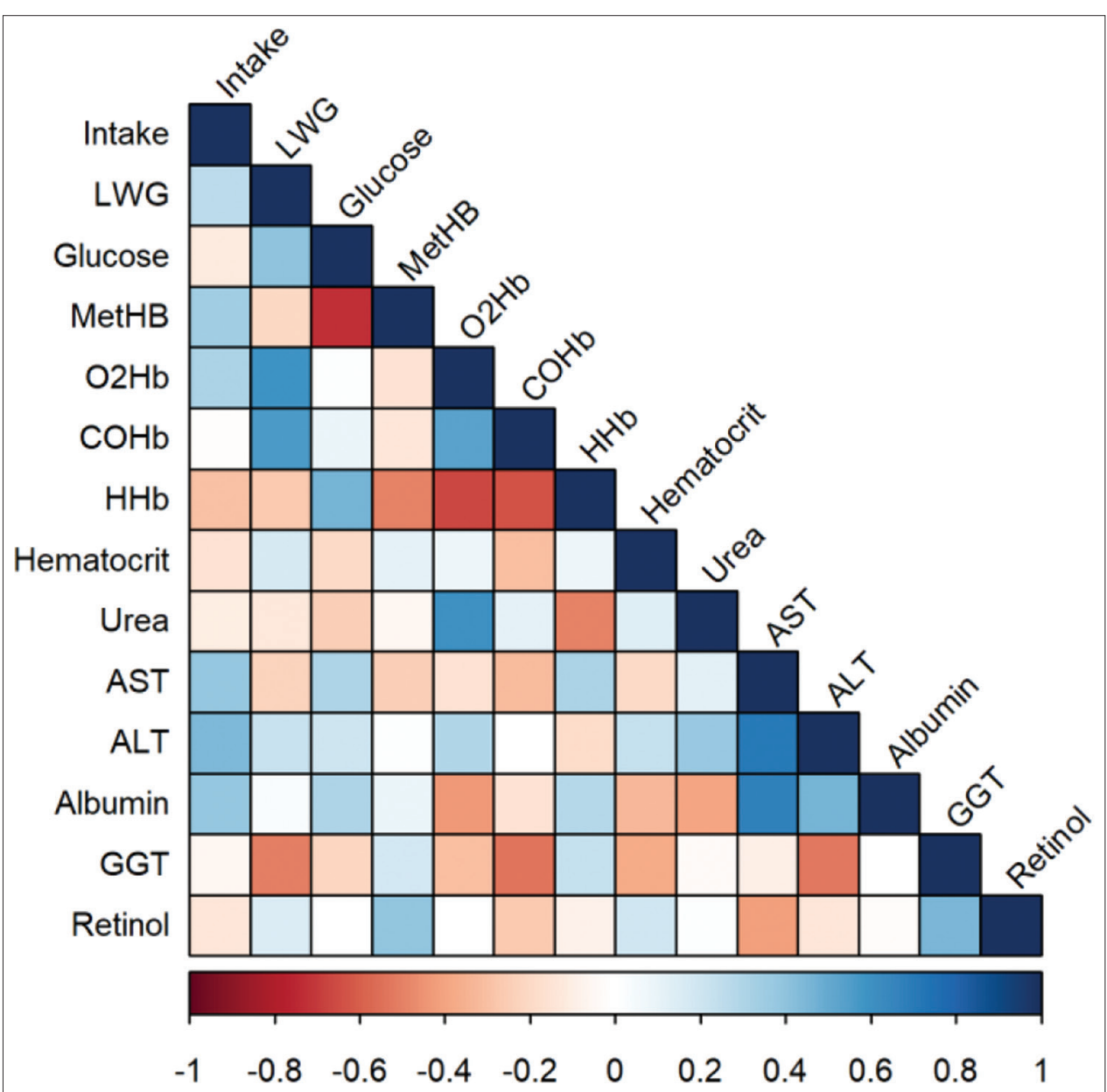

Figure-5: Correlogram of Spearman's correlation analysis between dry matter intake, LWG, and blood parameters (Glucose; MetHB=Methemoglobin; $\mathrm{O}_{2} \mathrm{Hb}=$ Oxyhemoglobin; $\mathrm{COHb}=$ Carboxyhemoglobin; $\mathrm{HHb}=$ Deoxyhemoglobin; Hematocrit; Urea; AST=Aspartate Aminotransferase; ALT=Alanine aminotransferase; Albumin; GGT=Gamma-glutamyl transpeptidase and retinol). The data of the blood parameters correspond to the $25^{\text {th }}$ day of adaptation to the diet $\left(100 \%\right.$ of $\left.\mathrm{NO}_{3}{ }^{-}\right)$. LWG $=$Live weight gain.

adaptation studies showed a $14-25 \%$ decrease in enteric $\mathrm{CH}_{4}$ emissions without affecting animal performance and animal health $[10,11,26,27]$. In this study, blood MetHb did not exceed the upper tolerance limits for cattle $(<10 \%$ of total hemoglobin) when fed daily with $15 \mathrm{~g}$ of $\mathrm{NO}_{3}^{-} / \mathrm{kg}$ of DM, but we noted that the individual response was variable $(\mathrm{CV}=38.4 \%)$. Moreover, the percentage of MetHb was positively associated with DMI, and negatively with LWG, $\mathrm{HHb}, \mathrm{O}_{2} \mathrm{Hb}$, and $\mathrm{COHb}$. Furthermore, although $\mathrm{NO}_{3}^{-}$ did not affect LWG, the numerical difference $(-100$ g) could be explained partially by the negative association between these variables. In the previous studies in beef and dairy cattle under a system of progressive adaptation to dietary $\mathrm{NO}_{3}^{-}$reported levels $<6 \%$ of blood MetHb [11,24]. Similar results were found using encapsulated $\mathrm{NO}_{3}^{-}[7]$.

The increase in serum urea concentrations according to the increase in dietary $\mathrm{NO}_{3}^{-}$was expected, since $\mathrm{NO}_{3}^{-}$in the rumen is reduced to $\mathrm{NH}_{3}$ by $\mathrm{NO}_{3}^{-}$-reducing microorganisms. Therefore, these increases can be attributed to a higher concentration of rumen $\mathrm{NH}_{3}$, as it is absorbed and converted to urea in the liver, then excreted through the urine [28].
Furthermore, the increased concentration of glucose is probably related to high urea concentration. This mechanism in ruminants is well documented and has been attributed either to a lower release of pancreatic insulin [29] or to increased glucose production in the liver [30]. However, some authors hypothesized the beneficial effects of using $\mathrm{NO}_{3}^{-}$and $\mathrm{NO}_{2}^{-}$as precursors of nitric oxide, at blood and tissue level, on glucose uptake and increased insulin sensitivity in humans and rats [31,32], but not confirmed yet in ruminants [33].

Overall, we can affirm that the progressive inclusion of $123 \mathrm{~g}$ of $\mathrm{NO}_{3}^{-} /$animal/day, caused an animal metabolic adjustment, due to a reduction of available oxygen caused by the increase of blood MetHb induced a higher glucose concentration and a reduction of hematocrit because aerobic metabolism at cellular and tissue level was affected by the reduction of oxygen availability [34]. However, animals with higher MetHb levels did not always induce higher glucose concentration, showing a negative correlation between both variables. The reason for these findings remains unclear.

Recently, González Delgado et al. [34] studied the acute effects of $\mathrm{NO}_{3}^{-}$poisoning in Wistar rats. The 
authors observed an increase in glucose, cholesterol, triglycerides, LDH, AST, and ALT that associated with changes in liver metabolism caused by liver damage. Moreover, other study reported that levels of $\mathrm{LDH}, \mathrm{AST}$, and ALT were increased under the chronic condition of $\mathrm{NO}_{3}^{-}$exposure in pregnant cows [35]. However, in this study, no significant increase in liver enzymes was observed after $\mathrm{NO}_{3}^{-}$inclusion. These different results are probably due to $\mathrm{NO}_{3}^{-}$exposure time, physiological status of the animal, animal species, and dose levels of $\mathrm{NO}_{3}^{-}$, time of adaptation to $\mathrm{NO}_{3}^{-}$, among other factors.

We can confirm the hypothesis that the progressive inclusion of $\mathrm{NO}_{3}^{-}$allows an effective adaptation of the $\mathrm{NO}_{3}^{-}$-reducing ruminal microbiota, without reaching toxicity levels for the animal, nor causing changes in animal performance. There were no changes in DMI, LWG, nor ALT and GGT activity, or albumin concentration by $\mathrm{NO}_{3}^{-}$inclusion in the diet, except for MetHb, urea, glucose, AST, and retinol concentrations that were significantly increased. However, these increases did not exceed the reference values of clinically healthy cattle [36-38].

\section{Conclusion}

This study confirmed that the progressive inclusion of $123 \mathrm{~g}$ of $\mathrm{NO}_{3}^{-} / \mathrm{animal} /$ day in the diet could provide safe supplementation for Holstein calves without affecting DMI and LWG. In turn, a dose-response effect of the MetHb, glucose, urea, AST, and retinol was observed, but these values did not exceed reference values. These results highlighted the importance of using a scheme of progressive inclusion of $\mathrm{NO}_{3}^{-}$in the diet of calves to reduce the risks of $\mathrm{NO}_{3}^{-}$toxicity.

\section{Authors' Contributions}

AO designed and performed the experiments, analyzed, and wrote the manuscript. GM, GD, and FS contributed in handling the animals, sample collection, and analyzed the data. MDT, JG, CF, and SLC contributed reagents/materials and analyzed the data. $\mathrm{AC}$ designed the experiment and analyzed the data. MEC conceived and designed the experiments, analyzed the data, and reviewed drafts of the paper. All authors have checked and approved the final version of the manuscript.

\section{Acknowledgments}

This study was supported by a grant from the FONCYT-Argentina: PICT-Project Number 2015294. We wish to thank Dra Delfina Montiel and Vet. Damian Castro for their technical assistance. We also thanks English Language editing and review services supplied by the Academic Translation Centre of the UTN Buenos Aires.

\section{Competing Interests}

The authors declare that they have no competing interests.

\section{Publisher's Note}

Veterinary World remains neutral with regard to jurisdictional claims in published institutional affiliation.

\section{References}

1. Lee, C. and Beauchemin, K.A. (2014) A review of feeding supplementary nitrate to ruminant animals: Nitrate toxicity, methane emissions, and production performance. Can. J. Anim. Sci., 94(4): 557-570.

2. Latham, E.A., Anderson, R.C., Pinchak, W.E. and Nisbet, D.J. (2016) Insights on alterations to the rumen ecosystem by nitrate and nitrocompounds. Front. Microbiol., 7: 228.

3. Kemp, A., Geurink, J.H., Haalstra, R.T. and Malestein, A. (1977) Nitrate poisoning in cattle. 2. Changes in nitrite in rumen fluid and methemoglobin formation in blood after high nitrate intake. Netherlands J. Agric. Sci., 25(1): 51-62.

4. Yaremcio, B. (1991) Nitrate poisoning and feeding nitrate feeds to livestock. [Online]Available:https://www1.agric. gov.ab.ca/\$department/deptdocs.nsf/all/agdex $851 / \$-$ file/0006001.pdf. Retrieved on 22-08-2018.

5. Bruning-Fann, C.S. and Kaneene, J.B. (1993) The effects of nitrate, nitrite, and N-nitroso compounds on animal health. Vet. Hum. Toxicol., 35(3): 237-253.

6. Beauchemin, K.A., Ungerfeld, E.M., Eckard, R.J. and Wang, M. (2020) Review: Fifty years of research on rumen methanogenesis: Lessons learned and future challenges for mitigation. Animal, 14(1): S2-S16.

7. Lee, C., Araujo, R.C., Koenig, K.M. and Beauchemin, K.A. (2015) Effects of encapsulated nitrate on eating behavior, rumen fermentation, and blood profile of beef heifers fed restrictively or ad libitum. J. Anim. Sci., 93(5): 2405-2418.

8. Zhang, X., Medrano, R.F., Wang, M., Beauchemin, K.A., Ma, Z., Wang, R., Wen, J., Bernad, L.A. and Tan, Z. (2019) Effects of urea plus nitrate pretreated rice straw and corn oil supplementation on fiber digestibility, nitrogen balance, rumen fermentation, microbiota and methane emissions in goats. J. Anim. Sci. Biotechnol., 10: 6.

9. Guyader, J., Doreau, M., Morgavi, D.P., Gerard, C., Loncke, C. and Martin, C. (2016) Long-term effect of linseed plus nitrate fed to dairy cows on enteric methane emission and nitrate and nitrite residuals in milk. Animal, 10(7): 1173-1181.

10. van Zijderveld, S.M., Gerritis, W.J.J., Dijkstra, J., Newbold, J.R., Hulshof, R.B.A. and Perdok, H.B. (2011) Persistency of methane mitigation by dietary nitrate supplementation in dairy cows. J. Dairy Sci., 94(8): 4028-4038.

11. Olijhoek, D.W., Hellwing, A.L.F., Brask, M., Weisbjerg, M.R., Højberg, O., Larsen, M.K., Dijkstra, J., Erlandsen, E.J. and Lund, P. (2016) Effect of dietary nitrate level on enteric methane production, hydrogen emission, rumen fermentation, and nutrient digestibility in dairy cows. J. Dairy Sci., 99(8): 6191-6205.

12. Wang, R., Wang, M., Ungerfeld, E.M., Zhang, X.M., Long, D.L., Mao, H.X., Deng, J.P., Bannik, A. and Tan, Z.L. (2018) Nitrate improves ammonia incorporation into rumen microbial protein in lactating dairy cows fed a low-protein diet. J. Dairy Sci., 101(11): 9789-9799.

13. Leng, R.A., Preston, T.R. and Inthapanya, S. (2012) Biochar reduces enteric methane and improves growth and feed conversion in local yellow cattle fed cassava root chips and fresh cassava foliage. Livest. Res. Rural Dev., 24(11): 199.

14. Doumas, B.T., Ard Watson, W. and Biggs, H.G. (1971) Albumin standards and the measurement of serum albumin with bromcresol green. Clin. Chim. Acta., 31(1): 87-96.

15. Szasz, G. (1974) Gamma-glutamyltranspeptidase. In: Bergmeyer, H.U., editor. Methoden der Enzymatis Chen Analyse. Verlag Chemie, Washington, DC. p757.

16. Thefeld, W., Hoffmeister, H., Busch, E.W., Koller, P.U. and Vollmar, J. (1974) Referenzwerte für die bestimmungen 
der transaminasen GOT und GPT sowie der alkalischen phosphatase im serum mit optimierten standard methodsen. Dtsch. Med. Wochenschr., 99(8): 343-351.

17. AOAC. (1990) Official Methods of Analysis. $15^{\text {th }}$ ed. AOAC Chemist, Washington, DC, USA.

18. Van Soest, P.J., Robertson, J.B. and Lewis, B.A. (1991) Methods for dietary fiber, neutral detergent fiber, and nonstarch polysaccharides in relation to animal nutrition. $J$. Dairy Sci., 74(10): 3583-3597.

19. MacRae, J.C. and Armstrong, D.G. (1968) Enzyme method for determination of $\alpha$-linked glucose polymers in biological materials. J. Sci. Food Agric., 19(10): 578-581.

20. SAS. (2013) SAS/STAT ${ }^{\circledR} 13.1$ User's Guide. SAS Institute Inc., Cary, NC.

21. R Core Team. (2019) R: A Language and Environment for Statistical Computing. R Foundation for Statistical Computing, Vienna, Austria.

22. Leng, R.A. (2008) The Potential of Feeding Nitrate to Reduce Enteric Methane Production in Ruminants. Report to Department of Climate Change, Commonwealth Government, Canberra.

23. Hulshof, R.B.A., Berndt, A., Gerrits, W.J.J., Dijkstra, J., van Zijderveld, S.M., Newbold, J.R. and Perdok, H.B. (2012) Dietary nitrate supplementation reduces methane emission in beef cattle fed sugarcane-based diets. J. Anim. Sci., 90(7): 2317-2323.

24. Doreau, M., Arbre, M., Popova, M., Rochette, Y. and Martin, C. (2017) Linseed plus nitrate in the diet for fattening bulls: Effects on methane emission, animal health and residues in offal. Animal, 12(3): 501-507.

25. Newbold, J.R., van Zijderveld, S.M., Hulshof, R.B.A., Fokkimk, W.B., Leng, R.A., Terencio, P., Powers, W.J., van Adrichem, P.S.J., Paton, N.D. and Perdok, H.B. (2014) The effect of incremental levels of dietary nitrate on methane emissions in Holstein steers and performance in Nelore bulls. J. Anim. Sci., 92(11): 5032-5040.

26. Lund, P., Dahl, R., Yang, H.J., Hellwing, A.L.F., Cao, B.B. and Weisbjerg, M.R. (2014) The acute effect of addition of nitrate on in vitro and in vivo methane emission in dairy cows. Anim. Prod. Sci., 54(9): 1432-1435.

27. Klop, G., Hatew, B., Bannik, A. and Dijkstra, J. (2016) Feeding nitrate and docosahexaenoic acid affects enteric methane production and milk fatty acid composition in lactating dairy cows. J. Dairy Sci., 99(2): 1161-1172.
28. Abdoun, K., Stumpff, F. and Martens, H. (2007) Ammonia and urea transport across the rumen epithelium: A review. Anim. Health Res. Rev., 7(1-2): 43-59.

29. Fernandez, J.M., Croom, W.J. Jr., Tate, L.P. and Johnson, A.D. (1990) Subclinical ammonia toxicity in steers: Effects on hepatic and portal-drained visceral flux of metabolites and regulatory hormones. J. Anim. Sci., 68(6): 1726-1742.

30. Huntington, G.B., Harmon, D.L., Kristensen, N.B., Hanson, K.C. and Spears, J.W. (2006) Effects of a slow-release urea source on absorption of ammonia and endogenous production of urea by cattle. Anim. Feed Sci. Technol., 130(3): 225-241.

31. Lundberg, J.O., Weitzberg, E. and Gladwin, M.T. (2008) The nitrate-nitrite-nitric oxide pathway in physiology and therapeutics. Nat. Rev. Drug Discov., 7(2): 156-167.

32. Khalifi, S., Rahimipour, A., Jeddi, S., Ghambari, M., Kazerouni, F. and Ghasemi, A. (2015) Dietary nitrate improves glucose tolerance and lipid profile in an animal model of hyperglycemia. Nitric. Oxide., 44: 24-30.

33. Villar, M.L., Godwin, I.R., Hegarty, R.S., Dobos, R.C., Smith, K.A., Clay, J.W. and Nolan, J.V. (2019) The effects of dietary nitrate on plasma glucose and insulin sensitivity in sheep. J. Anim. Physiol. Anim. Nutr., 103(6): 1657-1662.

34. González Delgado, M.F., González Zamora, A., Gonsebatt, M.E., Meza Mata, E., Garcia Vargas, G.G., Calleros Rincon, E.Y. and Pérez Morales, R. (2018) Subacute intoxication with sodium nitrate induces hematological and biochemical alterations and liver injury in male Wistar rats. Ecotoxicol. Environ. Saf., 166: 48-55.

35. Sezer, K., Albay, M.K., Ozmen, O., Haligur, M., Sahinduran, S., Mor, F. and Koker, A. (2011) Hematological, biochemical and thyroid gland investigations in pregnant cows and in calves chronically intoxicated with nitrate. Rev. Med. Vet., 5(162): 223-228.

36. Bouda, J. (1984) Biochemical and hematological reference values in calves and their significance for health control. Acta Vet. Brno., 53(3-4): 137-142.

37. Kaneko, J.J., Harvey, J.W. and Bruss, M.L. (2008) Clinical Biochemistry of Domestic Animals. $6^{\text {th }}$ ed. Elsevier Science, Netherlands. p928.

38. Kahn, C.M. and Line, S. (2010) Reference guides. In: The Merck Veterinary Manual. Elsevier Health Sciences, Netherlands. p2581. 